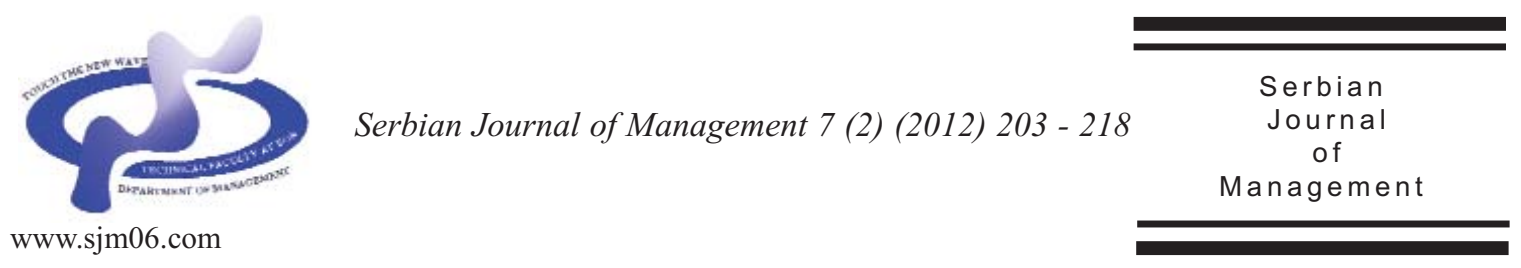

\title{
AN EMPIRICAL EXAMINATION OF THE RELATIONSHIPS BETWEEN SERVICE QUALITY, SATISFACTION AND BEHAVIORAL INTENTIONS IN HIGHER EDUCATION SETTING
}

\author{
Jaroslav Dado ${ }^{a}$, Janka Taborecka Petrovicova ${ }^{a}$, Sreten Cuzovic ${ }^{b}$ and Tamara Rajic ${ }_{*}$

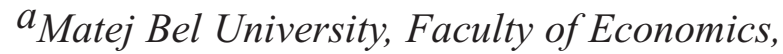 \\ Tajovskeho 10, 97401 Banska Bystrica, Slovakia \\ ${ }^{b}$ University of Nis, Faculty of Economics, Trg Kralja Aleksandra 11, 18000 Nis, Serbia \\ ${ }^{c}$ University of Belgrade, Technical faculty in Bor, Vojske Jugoslavije 12, 19210 Bor, Serbia
}

(Received 23 November 2011; accepted 16 December 2011)

\begin{abstract}
The main aim of this study is to examine the relationship between service quality and customer satisfaction and their impact on behavioral intentions in higher education setting in Serbia. Two competing models, revealed during the literature review, have been tested on a sample of Engineering Management students by means of structural equation modeling, performed via LISREL 8 . Results of the study indicate that satisfaction is influenced by service quality and directly related to behavioral intentions, thus offering support for Oliver's (1999) cognition-affect-conation sequence of causal relationships in loyalty formation. Implications of the study have been discussed and limitations and directions for future research are outlined.
\end{abstract}

Keywords: Service quality, customer satisfaction, behavioral intentions, structural equation modeling, higher education

\section{INTRODUCTION}

In an increasingly competitive environment service quality and customer satisfaction take on paramount importance as the main drivers of customer loyalty. Empirical work suggests that providing superior service quality and higher levels of satisfaction lead to greater customer loyalty, secure future revenues, reduce the costs of future transactions through positive referrals, decrease price elasticity and ultimately affect company's bottom line (Anderson et al., 1997). Service industries recorded an unprecedented growth in the second half of XX century. At the beginning of new millennium services have already been recognized as a major wealth-producer and

*Corresponding author: trajic@tf.bor.ac.rs

DOI: $10.5937 /$ sjm.v7i2.1245 
job-creator (OECD, 2000) and the share of service sector in the overall economic activity is expected to rise. In line with predominance of service industries the constructs of service quality, customer satisfaction and loyalty, their nature, determinants and relationships, have gained the attention of researchers in various B2C and B2B service settings.

These constructs have recently started to gain increasing attention among researchers in the field of higher education (Gremler \& McCollough, 2002; Arambewela \& Hall, 2006; Helgesen \& Nesset, 2007). Research on the topic has been fuelled by prevailing trends in the sector of higher education. It has been affected by a number of changes over the previous decade, including aspirations of higher education institutions towards membership in international education and research alliances, increased global competition, change of funding formulas of higher education and higher rates of participation of tuition-paying students. Development of a 'Europe of knowledge', in addition to Europe of euro and the economy, has raised the issue of quality of higher education services for all its stakeholders (Sursock \& Smidt, 2010). Trade in higher education services within the framework of GATS has become today's reality. It is estimated to be a billion dollar business, including recruitment of international students, franchised provision of educational services, establishment of university campuses abroad and proliferation of e-learning modes (Knight, 2002). Consequently, student retention, and service quality and customer satisfaction as its determinants, have gained the status of primary concern of academic communities worldwide.
However majority of studies on service quality and customer satisfaction, their relationship and impact on customer behavioral intentions, have been from an ethnocentric, US perspective, resulting in the inability to generalize conclusions crossculturally, whereas developing countries have largely been neglected. This also pertains to Serbia and its context of higher education, where these constructs have been predominantly addressed on conceptual basis. With the aim of fulfilling the gap in empirically-based recommendations the authors of this paper set out to investigate the relationship between service quality and customer satisfaction and their influence on student behavioral intentions. Moreover, simultaneous examination of multiple dependence relationships has been largely neglected in previous works related to students' perceptions of service quality, satisfaction and loyalty. Consequently, the aforementioned notion offers support for modeling the relationships between service quality, customer satisfaction and loyalty in higher education setting.

The remainder of the paper is structured as follows. First, literature review concerning the constructs of service quality, customer satisfaction, their nature, relationships and influence on customer behavioral intentions yielding to two competing models has been presented, succeeded by a brief overview of measures included in the study, data collection and methods used in data analysis. This is followed by the results of the study, whereas subsequent section deals with implications, limitations and suggestions for further research. 


\section{CONCEPTUAL FRAMEWORK}

\subsection{Service quality}

A rapid acceleration of academic interest in service quality was initiated in 1980s when businesses recognized service quality as a key point of differentiation and a safe route to above the average performance (Gupta et al., 2005). Service quality has been said to be ,a rather abstruse and abstract concept that is difficult to define and measure" (Sureshchandar et al., 2002, p.33). According to Parasuraman et al. (1985, p.41) service quality is an ,elusive and indistinct construct", which cannot be measured in an objective manner like product quality. What makes it difficult to define and measure service quality is the very essence of services, i.e. intangibility, heterogeneity and inseparability of production and consumption as their main characteristics (Parasuraman et al., 1985). Empirical studies, conducted by Parasuraman et al. (1985, 1988, 1991), resulted in SERVQUAL, 22-item scale for measuring service quality along five dimensions, those being reliability, responsiveness, assurance, empathy and tangibles. The construct of service quality, as measured by SERVQUAL, involves perceived service quality, which originators of the scale define as "the consumer's judgment about an entity's overall excellence or superiority" (Parasuraman et al., 1988, p.15), adding further that "it is a form of attitude, related but not equivalent to satisfaction" (p.15) which results from a comparison of perceived performance and expectations. Due to its intuitive and appealing notion a number of studies conducted across a wide spectrum of service industries have also invoked the SERVQUAL framework. The scale has drawn the attention of researchers in the field of higher education, as well (Hill, 1995; Cuthbert, 1996a; Cuthbert 1996b; O’Neill, 2003; Douglas et al., 2006; Barnes, 2007; Sultan \& Wong, 2010; Dado et al., 2011). However replication of its fivedimensional structure has been more of an exception than a practice, which has caused numerous conceptual and operational criticisms of the SERVQUAL instrument (see e.g. Buttle, 1996; Asubonteng et al., 1996). Among most cited objections is an improper perception-minus-expectation foundation of the SERVQUAL approach. Cronin and Taylor (1992) argue that if service quality is an attitude, then it should be also measured as an attitude, using performance-only items, instead of the calculation of the gap between perceived performance and expectations. The authors further state that only the model that used performance-based scale was consistently supported in all four samples included in the study. A number of other studies report on superiority of performance-based measurement of service quality (Brown et al., 1993; Lee et al., 2000; Brady et al., 2002; Olorunniwo et al., 2006). Due to an increasing body of research that provides support for performance-based measurement of service quality, performance-only measures have been adopted in this study also.

\subsection{Customer satisfaction and loyalty}

Early definitions of satisfaction evolved in the areas of job, self, life and patient satisfaction (Oliver, 1980). It was initially related to need fulfillment, pleasure/displeasure, evaluation of the purchase/consumption experience, comparison of actual with ideal outcomes 
and the benefits of consumption. Oliver (1981) defines satisfaction as "the summary psychological state resulting when the emotion surrounding disconfirmed expectations is coupled with the consumer's prior feelings about the consumption experience" (p.27). Andreassen and Lindestad (1998) support this view in a service setting, claiming that satisfaction is the result of comparison of expectations prior to purchase and consumption with service performance, whereas positive disconfirmation increases or maintains satisfaction while negative disconfirmation creates dissatisfaction. The construct has been described as "an inherently unstable and temporary mental state "(Reichheld, 1996; p.59) and as an active, dynamic process, with a strong social dimension, which is context-dependent and invariably intertwined with life satisfaction and the quality of life itself (Fournier \& Glen Mick, 1999; p.14). Two different conceptualizations of the construct of satisfaction can be distinguished in marketing literature, transaction-specific and cumulative satisfaction, whereas former can be described as a post-choice evaluative judgement of a specific purchase occasion and latter relates to an overall evaluation based on the total consumption experience with a product or service over time (Jones \& Suh, 2000; Shankar et al., 2003; Vilares \& Coelho, 2003). The latter perspective has been adopted in this study also. In marketing theory and practice customer satisfaction has long been regarded as a central concept and an important aim of all business activities. Anderson et al. (1994, p.55) claim that ,increasing customer satisfaction increases the value of a firm's customer assets and future profitability“. The authors further argue that satisfied customers are more tolerant of price increases, due to the benefits they received from the company and for which they are willing to pay more. They buy more frequently, in greater volumes and are eager to try new goods and services from the company that makes them satisfied. The costs of attracting new customers are expected to be lower for the companies that have a base of highly satisfied customers, due to their engagement in spreading positive word of mouth. Oliver (1999) however highlights that although satisfaction is a necessary prerequisite of true loyalty, it does not universally translate into loyaty.

As majority of the studies related to customer loyaty originated in the field of consumer goods strong emphasis has been put on repurchase behavior as an indicator of loyalty. Bloemer et al. (1999) emphasize that this is a narrow and outcome-focused view of loyalty, which is in fact a dynamic process. The authors further argue that the absence of repeat purchases may as well be the result of non-availability or other situational factors and stress the importance of getting deeper insights into customer's preferences and future behavioral intentions as more important indicators of customer loyalty. Moreover, repeat purchasing may as well be caused by reasons that have nothing in common with true loyalty, such as lack of alternatives, high switching costs, buying out of inertia (Athanassopoulos et al., 2001; Lam et al. 2004) This point of view is also supported by Oliver (1999) who defined loyalty as ,a deeply held commitment to rebuy or repatronize a preferred product/service consistently in the future, thereby causing repetitive same-brand or same brand-set purchasing, despite situational influences and marketing efforts having the potential to cause switching behavior" (p.34). The author describes four 
sequential stages of loyalty formation. Customers first become loyal in a cognitive sense, later in an affective sense, which is followed by conative loyalty and the final stage is action loyalty. Cognitive loyalty is based on direct experience or vicarious knowledge of performance superiority of preferred alternative. Affective loyalty is a deeper level of commitment in comparison with previous stage which is based on liking of a brand due to cumulatively satisfying usage occasions. The following stage is conative loyalty. i.e. behavioral intention stage, which relates to motivation to rebuy product or service again, whereas in the stage of action loyalty previous motivation towards the brand transforms into readiness to act. Therefore loyalty is a complex process and due to aforementioned trends in higher education it has been gaining incresing attention among researchers in this field. It has been stressed in the literature that advantages to educational institution of having loyal students should not be related only to the period a student spends at university, but that they are at their greatest after the student graduates. According to Hennig-Thurau et al. (2001) universities benefit from satisfied graduates enrolling higher level studies as tuition-paying students, the costs of attracting new students are lower due to positive referrals of satisfied students, active participation of satisfied students in the process of teaching is expected to positively influence quality of teaching and satisfied graduates acting as visiting lecturers in the future enhance overall experience of current students. Thus more than in any other service business satisfaction and loyalty of former customers should matter to educational institutions.
2.3. Relationship between service quality, customer satisfaction and loyalty

Spurred on by the original work of Parasuraman et al. (1985) service quality and customer satisfaction have gained considerable interest among practitioners and researchers in the field of Services Marketing. The fact that both constructs are based on expectancy-disconfirmation paradigm has led some authors to conclude that service quality and customer satisfaction are the same and that the difference between them is more of a semantic than of an intrinsic nature (Tian-Cole et al., 2003). Iacobucci et al. (1995) on a sample of business administration students conclude that quality and satisfaction are a single construct, whereas Spreng and Mackoy (1996) report high correlation between the constructs but still conclude that although similar, service quality and satisfaction are essentially distinct constructs. Literature review reveals numerous differences between service quality and customer satisfaction. Parasuraman et al. (1988) argue that service quality evaluation is based on normative, i.e. what a service provider should offer, expectations, whereas satisfaction judgment is based on predictive, i.e. what is likely to happen, expectations. The authors further claim that service quality is a long-run, overall evaluation whereas satisfaction is a transaction-specific evaluation. It has been also posited that it is not necessary for a customer to have direct experience with a service to judge its quality whereas customers must have experienced a service to determine how satisfied they are with it (Anderson et al., 1994).

Although numerous researchers generally agree that service quality and customer satisfaction are distinct, but related 
constructs, the issue of causal order between them, and their influence on behavioral intentions, has not come to its resolution yet. Results of the multi-industry study conducted by Cronin and Taylor (1992) revealed significant influence of service quality on satisfaction, which was directly related to purchase intentions. The sequence of relationships revealed in this study supports Oliver's (1999) cognitive-affectiveconative framework. Wiers-Jensen et al. (2002) report quality of teaching as the most important determinant of student satisfaction, whereas Helgesen and Nesset (2007) find support for service quality $\rightarrow$ satisfaction $\rightarrow$ loyalty sequence of relationships in Norwegian higher education setting. Other empirical studies also provide support for this succession of relationships (Gotlieb et al., 1994; Baker \& Crompton, 2000; Dabholkar et al., 2000; Brady et al., 2002, Deng et al., 2010). In an examination of the influence of service quality and merchandize quality on store traffic and sales growth Babakus et al. (2004) report mediating effect of customer satisfaction. The contention that service quality does not directly influence behavioral intentions is also supported by Lonial et al.'s (2010) research performed on a sample of health care customers.

Counter to the aforementioned perspective, some researchers have modeled service quality as an antecedent to behavioral intentions and found empirical support for this causal order. On a sample of MBA students Boulding et al. (1993) report significant influence of perceived service quality on students' intentions of spreading positive word of mouth about the school to people outside the school and willingness to recommend the school to one's employer as a place to recruit. Zeithaml et al. (1996) in a multi-industry study offer strong support for the influence of service quality on customers' behavioral intentions. Bloemer et al. (1999) found significant influence of service quality dimensions on customers' willingness to recommend, repurchase intentions and price sensitivity. Relationship between service quality and satisfaction is not bereft of opposite views, as well. Thus Parasuraman et al. (1988) claim that incidents of satisfaction over time lead to customers' perceptions of service quality. Bitner (1990) proposed a model of service encounter evaluation and empirically supported the effect of satisfaction on service quality and direct relatedness of service quality to behavioral intentions.

Literature review clearly indicates opposite reports relative to the ordering of service quality, customer satisfaction and behavioral intentions. On the basis of previous findings two conceptual models are proposed, as presented in Figure 1. The main question of this study is what is the causal order between service quality, satisfaction and behavioral intentions in Serbian higher education setting. In order to give answer to this question competing models are subjected to further examination, whereas the superiority of one model over the other will be assessed on the basis of fit indices, and in line with the suggestion made by Brady and Robertson (2001) on the ability of the models to explain variance in behavioral intentions.

Despite reverse theories, causal order which implies the influence of service quality on customer satisfaction has received the strongest support by researchers. Therefore, the following has been put forward: 
Model 1. SQ $\rightarrow$ Sat $\rightarrow$ BI

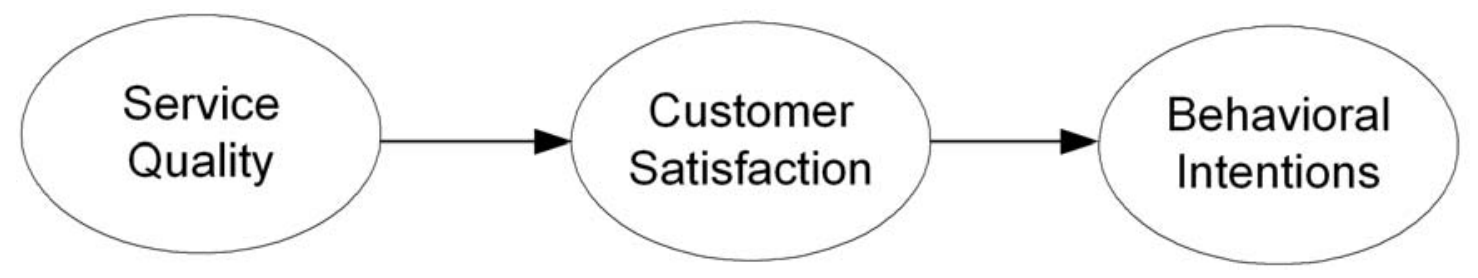

Model 2. Sat $\rightarrow \mathrm{SQ} \rightarrow \mathrm{BI}$

items not related to students' perceptions of

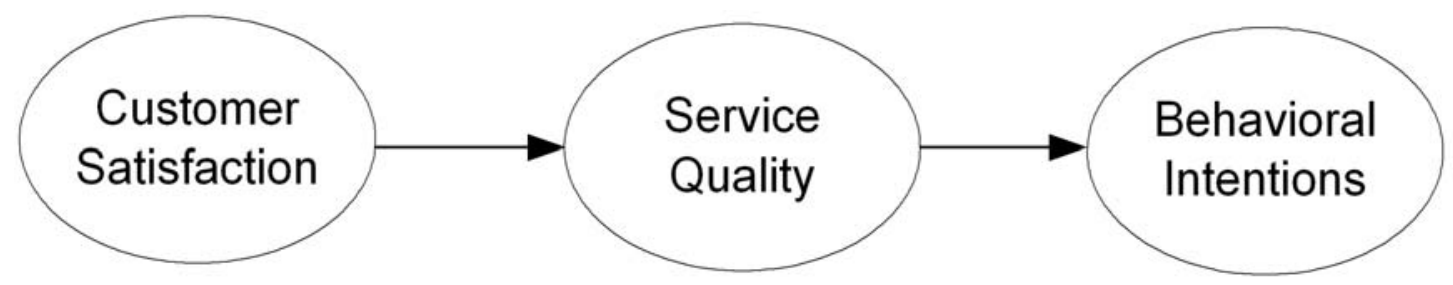

Figure 1. Conceptual models

H1: Model 1 fits the data better than Model 2;

H2: Model 1 is superior to Model 2, on the grounds of explained variance in behavioral intentions.

\section{RESEARCH METHODOLOGY}

\subsection{Measures and data collection}

Measures used in this research are based on the indicators applied in previous studies related to service quality, satisfaction and behavioral intentions. SERVQUAL scale was used as the starting point for service quality indicators. In line with the suggestions made by Cronin and Taylor (1992) and the originators of the scale who claim that SERVQUAL is ,a useful starting point, not the final answer for assessing and improving service quality" (Parasuraman et al., 1991, p.445), the scale items have been adapted to the context of higher education. Extensive qualitative study conducted on a sample of students by means of group discussions resulted in the substitution of the service quality with the statements deemed more important for the context of examination. In line with previous studies of the subject (Cronin et al., 2000) and in order to preserve parsimony of the analysis a group of importance items accounting for the highest percent of explained variance in the data was chosen as representative of service quality construct. Approachability of professors, having students' best interest at heart, professors' sincere interest in instilling knowledge, encouraging active participation of the students during the process of teaching and motivating students to do their best have been recognized as the main traits of professors' behavior which lead to students' perceptions of higher education service quality. This is in line with previously stated importance of service personnel' behavior and their relationship with customers for the perceptions of service quality (Parasuraman et al., 1985; Mandhachitara \& Poolthong, 2011). Satisfaction was measured by four items, similar to those used by Cronin et al. (2000) and Chi and Gursoy (2009). Students were asked to indicate their agreement with the 
statement that the faculty offers exactly the services that can be expected from a higher education institution and to specify to what extent higher education services provided by the institution make them satisfied, happy and delighted. The construct of behavioral intentions was assessed by the items proposed by Zeithaml et al. (1996) and also used by Bloemer et al. (1999). Likelihood of saying positive things about the faculty, recommending Engineering Management at Technical faculty in Bor to a friend or family member who is about to enroll higher education studies and probability of making the same choice if the student had to do it all over again were used as indicators of behavioral intentions. All the items were accompanied with a seven-point Likert-type scale ranging from (1) Strongly disagree to (7) Strongly agree, excluding verbal description for the points between the opposites of the scale.

Extensive qualitative research was proceeded with quantitative study whereas students' responses on questionnaire items were collected during the classes, in agreement with teaching staff who allowed a part of their lecture time to be taken for data collection. This personal approach yielded 293 fulfilled questionnaires. Less than 10 percent categorized as 'yeah-saying' and incomplete questionnaires were excluded from further analysis.

\subsection{Data Analysis}

Data are analyzed using structural equation modeling (SEM) via LISREL 8. Maximum likelihood is chosen as a method of parameter estimation. Two-step approach, proposed by Anderson and Gerbing (1988) is applied in data analyses. Confirmatory factor analysis was performed first in order to assess psychometric properties of the constructs, i.e. construct validity. Fit of the structural models and their ability to explain variance in behavioral intentions are assessed in the following stage. Results of the measurement and structural analyses are presented in the following section.

\section{RESULTS}

\subsection{Measurement model fit}

Chi-sqare test $\left(\chi^{2}\right)$ has gained the status of the most widely used statistical test for an assessment of goodness-of-fit of a model. It tests the Null hypothesis that the observed covariance matrix corresponds to a modelimplied matrix (Fornell \& Larcker, 1981). Researchers tend to come up with statistically insignificant $\chi 2$ value, due to the fact that statistical significance leads to the rejection of the Null hypothesis and the conclusion that the model does not fit the date well. The overall model fit as indicated by $\chi^{2}$ statistic was unsatisfactory $(\chi 2=134.413 ; \mathrm{df}=86, \mathrm{p}<0,01)$. However, according to Bentler (1980) in large samples $(n \geq 200)$ almost any model tends to be rejected and thus it is preferable to supplement $\chi 2$ value with normed chi-square statistic $(\chi 2 / \mathrm{df})$, whereas ratio up to 2,5 indicates acceptable model fit (Kunnan, 1998). Dividing $\chi 2$ value by degrees of freedom yielded normed chi-square statistic of 1,56. Assessing model fit researchers have generally relied on absolute fit indices, such as Goodness-of-Fit Index (GFI), which is analogues to the $\mathrm{R}^{2}$ value in multiple regression and Root Mean Square Error of Approximation (RMSEA) and various incremental fit indices, such as Non-Normed 
Fit Index (NNFI), Normed Fit Index (NFI) and Comparative Fit Index (CFI). With the exception of RMSEA, other indicators take values in the range between 0 and 1 and values higher than 0.90 indicate acceptable fit of the model to the data, whereas the higher the value, the better the fit (Molina et al., 2007). Acceptable values for RMSEA, a measure of the discrepancy per degree of freeedom between model-implied and sample covariance matrix, are those up to 0.50 , although values up to 0.80 indicate reasonable fit (Jackson, 2001). Results of the measurement analysis are reported in Table 1. Model fit as indicated by fit indices was deemed satisfactory which allowed moving into the next phase of the study, i.e. assessment of construct validity.

Extent to which a set of measured variables actually represents a latent construct which they are designed to measure (Hair et al., 2009) was examined by assessing convergent and discriminant validity. Convergent validity, i.e. the degree to which a set of items representing the same construct converge or share a high proportion of variance in common, was assessed in line with the suggestions made by Živković et al.
(2010). All t-values were higher than $| \pm 1,96|$ indicating significant factor loadings, whose magnitudes were from 0.713 to 0.766 for service quality, and $0.853-0.935$ for customer satisfaction and 0.631-0.886 for behavioral intentions. Factor loadings higher than 0.50 attested to convergent validity of the constructs. Composite reliability and average variance extracted, which measures the amount of variance explained by the construct, being higher than 0.70 and $50 \%$ respectively, for all the constructs, provide support for convergent validity of the constructs. Discriminant validity, i.e. the degree to which a construct is truly distinct from other constructs, was assessed by conducting confirmatory factor analysis for each pair of constructs, one at a time. Comparisons of default with nested models, whereas covariance between the constructs was constrained to 1 , revealed statistically significant worsening of fit of constrained models $\left(\Delta \chi^{2}(1)^{>4)}\right.$ thus indicating that the constructs are indeed distinct (Anderson \& Gerbing, 1988). Fit of the measurement model and acceptable construct validity allowed for the progression towards structural analysis.

Table 1. Measurement model fit

\begin{tabular}{|c|c|c|c|c|c|c|}
\hline$\chi^{2}$ & $\chi^{2} / \mathrm{df}$ & GFI & RMSEA & NNFI & NFI & CFI \\
\hline $\begin{array}{l}134,413(\mathrm{p}<0,01) \\
\text { Summary statistics }\end{array}$ & $134.413 / 86$ & 0.927 & 0.049 & 0.976 & 0.948 & 0.980 \\
\hline Constructs & $\begin{array}{l}\text { St.factor } \\
\text { loadings }\end{array}$ & t-values & $\begin{array}{l}\text { AVE } \\
(\%)\end{array}$ & $\begin{array}{l}\text { Composite } \\
\text { Reliability }\end{array}$ & & \\
\hline $\begin{array}{l}\text { Service Quality } \\
\text { Satisfaction }\end{array}$ & $\begin{array}{l}0.713-0.766 \\
0.853-0.935\end{array}$ & $\begin{array}{l}10.99-11.91 \\
17.42-20.36\end{array}$ & $\begin{array}{l}56 \\
79\end{array}$ & $\begin{array}{l}0.93 \\
0.87\end{array}$ & & \\
\hline $\begin{array}{l}\text { Behavioral } \\
\text { Intentions }\end{array}$ & $0.631-0.886$ & $10.63-15.77$ & 63 & 0.89 & & \\
\hline
\end{tabular}

Note: GFI = Goodness-of-Fit Index; RMSEA = Root Mean Square Error of Approximation; NNFI = Non-Normed Fit Index; NFI = Normed Fit Index; CFI = Comparative Fit Index; AVE $=$ Average Variance Extracted 


\subsection{Structural model fit}

According to Anderson and Gerbing (1988) two-step approach is particularly convenient framework for comparison of one model with some other, theoretically founded alternative. The authors further argue that the models are never confirmed, they rather gain support by failing to be disconfirmed and acceptable goodness-of-fit of one model does not necessarily imply that the model is the only possible combination of relationships between the constructs. This offers further support for comparison of two theoretically supported models, such as Model 1 and Model 2. Two competing patterns of relationships between service quality, satisfaction and behavioral intentions, presented in Figure 1, have been examined by means of structural equation modeling. The models are compared on the basis of absolute and incremental fit indices, however special emphasis has been put on two indices, NNFI and CFI, which are considered to be unaffected by sample size (Jackson, 2001). The results of the structural analysis are presented in Table 2.

Results of the structural analysis clearly indicate superiority of Model 1 to Model 2. Whereas fit of the Model 1 is excellent, according to fit indices, the fit of competing Model 2 is mediocre. Two of the fit indices that have been particularly emphasized, NNFI and CFI, are in the range of acceptable values for Model 2, being higher than 0.90, however all the other fit indices are lower than acceptable indicating scope for substantial improvement of Model 2. Results presented in Table 2 offer support for hypothesis $\mathrm{H} 1$. The following research question pertained to the superiority of one model over the other, in terms of explained variance in behavioral intentions. According to the results presented in Table 2 it appears that Model 1 is again superior in comparison with Model 2, due to the fact that the former explains $77 \%$ of variance in behavioral intentions compared to $38 \%$ explained by Model 2. These results offer support for hypothesis H2. Good model fit is established with recommended values of fit indices, significant structural coefficients and acceptably high $\mathrm{R}^{2}$ value, which are the traits of Model 1. The model implies that satisfaction is significantly influenced by service quality $(\gamma=0.62 ; \mathrm{t}=8.62)$ and directly related to behavioral intentions $(\beta=0.88$; $\mathrm{t}=14.69$ ). Indirect effect of service quality on behavioral intentions, through satisfaction is 0.54. Results of this study indicate that $\mathrm{SQ} \rightarrow \mathrm{Sat} \rightarrow \mathrm{BI}$ is the causal order of the constructs in Serbian higher education setting, thus providing support for Oliver's (1999) cognitive-affective-conative sequence of stages of loyalty development.

\section{DISCUSSION}

\subsection{Implications of the study}

The objective of this research was to examine the relationship between service quality and customer satisfaction and their impact on behavioral intentions in higher education setting. Results of the study indicate that both service quality and customer satisfaction are important determinants of behavioral intentions, whereas service quality is indirectly related to behavioral intentions, through satisfaction. High percent of explained variance in behavioral intentions of Model 1 indicates strong explanatory power of the model. 
Table 2. Results of the structural analysis

\begin{tabular}{|c|c|c|c|c|c|c|}
\hline \multirow{3}{*}{ Model 1} & Path & $\begin{array}{l}\text { Parameter } \\
\text { estimate }\end{array}$ & t-value & $\mathrm{R}^{2}$ & \multicolumn{2}{|l|}{ Fit Indices } \\
\hline & $\mathrm{SQ} \rightarrow$ Sat & 0.62 & 8.62 & 0.38 (Sat) & \multirow{3}{*}{$\begin{array}{l}\chi^{2} / \mathrm{df}=134.86 / 87 \\
\mathrm{RMSEA}=0.048 ; \\
\mathrm{NNFI}=0.977 ; \mathrm{CFI}=\end{array}$} & \multirow{2}{*}{$\begin{aligned} & \mathrm{GFI}=0.927 \\
& \mathrm{NFI}=0.948 \\
& 981\end{aligned}$} \\
\hline & $\mathrm{Sat} \rightarrow \mathrm{BI}$ & 0.88 & 14.69 & 0.77 (BI) & & \\
\hline $\begin{array}{l}\text { Indirect } \\
\text { Path }\end{array}$ & $\mathrm{SQ} \rightarrow \mathrm{Sat} \rightarrow \mathrm{BI}$ & $\begin{array}{l}0,54 \\
(\mathrm{p}<0.05)\end{array}$ & & & & \\
\hline \multicolumn{7}{|l|}{ Model 2} \\
\hline & $\mathrm{Sat} \rightarrow \mathrm{SQ}$ & 0.66 & 9.19 & $0.43(\mathrm{SQ})$ & $\chi^{2} / \mathrm{df}=283.43 / 87$ & $\mathrm{GFI}=0.874$; \\
\hline & $\mathrm{SQ} \rightarrow \mathrm{BI}$ & 0.62 & 8.48 & $0.38(\mathrm{BI})$ & \multicolumn{2}{|c|}{$\mathrm{NNFI}=0.904 ; \mathrm{CFI}=0.920$} \\
\hline
\end{tabular}

Consequently, it provides support for is more cost-effective to retain existing Oliver's (1999) cognitive-affective-conative customers than to attract new ones, gaining sequence of causal orders in loyalty deeper insights into the drivers of student formation. Both scholarly and managerial satisfaction would be undoubtedly beneficial implications are stemming from the study.

In spite of ample empirical support for $\mathrm{SQ} \rightarrow \mathrm{Sat} \rightarrow \mathrm{BI}$ sequence of relationships in US and over previous years increasingly in non-US service settings, relationships between these constructs have largly been understudied in Serbian service industries in a framework implying simultaneous examination of multiple dependence relationships. Shedding light on the relationship between service quality, customer satisfaction and behavioral intentions in higher education as a service industry, results of this study contribute to Services Marketing literature.

From a managerial perspective, results of this study indicate that although both higher education service quality and satisfaction are determinants of students' behavioral intentions, satisfaction exerts stronger influence on behavioral intentions than does service quality. Consequently, university administrators should focus their attention on more thorough examination of the determinants of student satisfaction. In line with frequently cited marketing axiom that it for appropriate budget allocations and right corrective actions, when needed. According to the Statistical Office of the Republic of Serbia a rise of $131 \%$ was recorded in selffinanced master students in Serbia in 2009, in comparison with 2007. An opportunity for additional revenue streams, by gaining higher share of tuition-paying students, should not be neglected and as it is suggested by the results of this study satisfied students are the ones willing to recommend the faculty and make the same choice again. Although satisfaction is more important determinant of future behavioral intentions, higher education service quality, as perceived by the students, should not be neglected either, due to its positive influence on behavioral intentions. Due attention should be paid to the determinants of service quality and perceived performance along those determinants. Moreover, in line with proper budget allocations, priorities regarding corrective actions should be set in accordance with relative importance of service quality dimensions for satisfaction judgments. 
5.2. Limitations and directions for further research

As it is the case with any research undertaking, this study is not bereft of limitations, as well. These limitations, however, serve as a potential fruitful avenue for future research. The main drawback of this study is the size and scope of its sample. Analyses were performed on a convenient sample of students attending one faculty. Thus external validity of causal inferences resulting from the study calls for their replication on more randomized sample of students, representative of higher education setting in Serbia. An inherent limitation of this study is its static perspective. According to O'Neill and Adrian (2001) who studied students' perceptions over time and concluded that the perceptions can change significantly and be quite different at the time when a purchase decision is being made, static perspective of this study should give way to longitudinal design in future research undertakings. As indicated by the results of this study both higher education service quality and satisfaction are important determinants of students' behavioral intentions, however the influence of satisfaction is stronger. It is worth noting however that service quality explains 38 percent of variance in student satisfaction which implies that there might be other factors, not related to service quality, which exert influence on student satisfaction. Perhaps students do not necessarily enroll the faculties with the image of ,highest quality“. Maybe some other factors, such as convenient location of the university, i.e. the distance from the home town and with it related overall costs of life, contribute to student satisfaction. Gaining deeper insight into the determinants of student satisfaction, besides service quality, would be particularly benefical. Although changing location in order to please the students would not be well advised, if location, and with it related costs of life, is important determinant of student satisfaction, it could be exploited as a unique selling proposition by higher education institutions displaced from the most attractive urban areas. University administrators therefore need to consider all of the possible determinants of student satisfaction and attempt to determine which of those will have the strongest impact on student behavioral intentions. There is obviously a scope for potential improvements in explanatory power which could be achieved by more comprehensive models in future studies. In order to make inferences regarding the relationship between service quality, customer satisfaction and behavioral intentions in Serbian service industries, future research should try to replicate this study in various service settings. Moreover, replication of this study in other national and cultural contexts would be valuable.

\section{References}

Anderson, E.W., Fornell, C. \& Lehmann, D.R. (1994) Customer Satisfaction, Market Share, and Profitability: Findings From Sweden, Journal of Marketing, 58:53-66.

Anderson, E.W., Fornell, C. \& Rust, R.T. (1997) Customer Satisfaction, Productivity and Profitability: Differences Between Goods and Services, Marketing Science, 16(2):129-145.

Anderson, J.C. \& Gerbing, D.W. (1988) Structural Equation Modeling in Practice: A Review and Recommended Two-Step Approach, Psychological Bulletin, 103(3): 411-423. 


\title{
ЕМПИРИЈСКО ИСТРАЖИВАҢЕ ОДНОСА ИЗМЕЪУ КВАЛИТЕТА УСЛУГА, САТИСФАКЦИЈЕ И ЛОЈАЛНОСТИ У СЕКТОРУ ВИСОКОГ ОБРАЗОВАЫА
}

\author{
Jaroslav Dado ${ }^{a}$, Janka Taborecka Petrovicova ${ }^{a}$, Sreten Cuzovic ${ }^{b}$, Tamara Rajic ${ } *$
}

Извод

Циљ овог рада је испитати везу између квалитета услуга и сатисфакције корисника и њихов утицај на бихејвиоралне намере корисника услуга у сектору високог образовања у Србији. Два модела, утврђена прегледом литературе, тестирана су на узорку студената Инжењерског менаџмента применом моделовања помоћу структурних једначина, спроведеног применом софтверског пакета ЛИСРЕЛ 8. Резултати истраживања указују на утицај квалитета услуга на сатисфакцију, која директно утиче на бихејвиоралне намере корисника, чиме је потврђен Оливеров (1999) модел који указује на след когниција-осећање-намера у формирању лојалности корисника. Размотрене су импликације које произилазе из ове студије и истакнута су ограничења и препоруке за будућа истраживања

Кључне речи: квалитет услуга, сатисфакција корисника, бихејвиоралне намере, моделованје помоћу структурних једначина, високо образовање

Andreassen, T.W. \& Lindestad, B. (1998) Customer loyalty and complex Services: The impact of corporate image on quality, customer satisfaction and loyalty for customers with varying degrees of service expertise, International Journal of Service Industry Management, 9 (1): 7-23

Arambewela, R. \& Hall, J. (2006) A Comparative Analysis of International Education Satisfaction Using SERVQUAL, Journal of Services Research, 6: 141-163

Asubonteng, P., McCleary, K.J. \& Swan, J.E. (1996) SERVQUAL revisited: a critical review of service quality, The Journal of Services Marketing, 10(6): 62-81

Athanassopoulos, A., Gounaris, S. \& Stathakopoulos, V. (2001) Behavioural responses to customer satisfaction: an empirical study, European Journal of Marketing, 35(5/6): 687-707

Babakus, E., Bienstock, C.C. \& Van
Scotter, J.R. (2004) Linking Perceived Quality and Customer Satisfaction to Store Traffic and Revenue Growth, Decision Sciences, 35(4): 713-737

Baker, D.A. \& Crompton, J.L. (2000) Quality, satisfaction and behavioral intentions, Annals of Tourism Research, 27(3): 785-804

Barnes, B.R. (2007) Analysing Service Quality: The Case of Post-Graduate Chinese Students, Total Quality Management, 18(3): 313-331.

Bentler, P.M. \& Bonett, D.G. (1980) Significance Tests and Goodness of Fit in the Analysis of Covariance Structures, Psychological Bulletin, 88(3): 588-606.

Bitner, M.J. (1990) Evaluating Service Encounters: The Effects of Physical Surroundings and Employee Responses, Journal of Marketing, 54(2): 69-82.

Bloemer, J., de Ruyter, K. \& Wetzels, M. 
(1999) Linking perceived service quality and 16.

service loyalty: a multi-dimensional perspective, European Journal of Marketing, 33(11/12): 1082-1106.

Boulding, W., Kalra, A., Staelin, R. \& Zeithaml, V.A. (1993) A Dynamic Process Model of Service Quality: From Expectations to Behavioral Intentions, Journal of Marketing Research, 30: 7-27.

Brady, M.K., Cronin, J.J. \& Brand, R.R. (2002) Performance-only measurement of service quality: a replication and extension, Journal of Business Research, 55: 17- 31.

Brady, M.K. \& Robertson, C.J. (2001) Searching for a consensus on the antecedent role of service quality and satisfaction: an exploratory cross-national study, Journal of Business Research, 51: 53- 60.

Brown, T.J., Churchill, G.A. Jr \& Peter, J.P. (1993) Improving the Measerement of Service Quality, Journal of Retailing, 69(1): 127-139.

Buttle, F. (1996) SERVQUAL: review, critique, research agenda, European Journal of Marketing, 30(1): 8-32.

Chi, C.G. \& Gursoy, D. (2009) Employee satisfaction, customer satisfaction, and financial performance: An empirical examination, International Journal of Hospitality Management, 28: 245-253.

Cronin, J.J. Jr., Brady, M.K. \& Hult, T.M. (2000) Assessing the Effects of Quality, Value and Customer satisfaction on Consumer Behavioral Intentions in Service Environments, Journal of Retailing, 76(2): 193-218.

Cronin, J.J. \& Taylor, S.A. (1992) Measuring Service Quality: A Reexamination and Extension, Journal of Marketing, 56: 55-68.

Cuthbert, P.F. (1996a) Managing service quality in HE: is SERVQUAL the answer? Part 1, Managing Service Quality, 6(2): 11-
Cuthbert, P.F. (1996b) Managing service quality in HE: is SERVQUAL the answer? Part 2, Managing Service Quality, 6(3): 31-35.

Dabholkar, P.A., Shepherd, D.C. \& Thorpe, D.I. (2000) A Comprehensive Framework for Service Quality: An Investigation of Critical Conceptual and Measurement Issues Through a Longitudinal Study, Journal of Retailing, 76(2): 139-173.

Dado, J., Taborecka-Petrovicova, J., Riznic, D. \& Rajic, T. (2011) An Empirical Investigation into the Construct of Higher Education Service Quality, International Review of Management and Marketing, 1(3): 30-42.

Deng, Z., Lu, Y., Kee, W.K. \& Zhang, J. (2010) Understanding customer satisfaction and loyalty: An empirical study of mobile instant messages in China, International Journal of Information Management, 30: 289-300.

Douglas, J., Douglas, A. \& Barnes, B. (2006) Measuring student satisfaction at a UK university, Quality Assurance in Education, 14(3): 251-267.

Fornell, C. \& Larcker, D.F. (1981) Evaluating Structural Equation Models with Unobservable Variables and Measurement Error, Journal of Marketing Research, 18(1): 39-50.

Fournier, S., Glen Mick, D. (1999) Rediscovering Satisfaction, Journal of Marketing, 63(4): 5-34.

Gotlieb, J.B., Grewal, D. \& Brown, S.W. (1994) Consumer Satisfaction and Perceived Quality: Complementary or Divergent Constructs?, Journal of Applied Psychology, 79(6): 875-885.

Gremler, D.D. \& McCollough, M.A. (2002) Student Satisfaction Guarantees: An Empirical Examination of Attitudes, 
Antecedents, and Consequences, Journal of Marketing Education, 24(2): 150-160.

Gupta, A., McDaniel, J.C. \& Herath, K.S. (2005) Quality management in service firms: sustaining structures of total quality service, Managing Service Quality, 15(4): 389-402.

Hair, J.F. Jr., Black, W.C., Babin, B.J. \& Anderson, R.E. (2009) Multivariate Data Analysis, 7th ed., Pearson Prentice Hall.

Helgesen, Ø. \& Nesset, E. (2007) What accounts for students' loyalty? Some field studyevidence, International Journal of Educational Management, 21(2): 126-143.

Hennig-Thurau, T., Langer, M.F. \& Hansen, U. (2001) Modeling and Managing Student Loyalty, Journal of Service Research, 3(4): 331-344.

Hill, F.M. (1995) Managing service quality in higher education: the role of the student as primary consumer, Quality Assurance in Education, 3(3): 10-21.

Iacobucci, D., Ostrom, A. \& Grayson, K. (1995) Distinguishing Service Quality and Customer Satisfaction: The Voice of the Customer, Journal of Consumer Psychology, 4(3): 277-303.

Jackson, D.L. (2001) Sample Size and Number of Parameter Estimates in Maximum Likelihood Confirmatory Factor Analysis: A Monte Carlo Investigation, Structural Equation Modeling, 8(2): 205223.

Jones, M.A. \& Suh, J. (2000) Transactionspecific satisfaction and overall satisfaction: an empirical analysis, Journal of Services Marketing, 14(2): 147-149.

Knight, J. (2002) Trade in Higher Education Services: The Implications of GATS, Observatory on Borderless Higher Education, London, www.unesco.org, (accessed 01 September 2011).

Kunnan, A.J. (1998) An introduction to structural equation modelling for language assessment research, Language Testing, 15(3): 295-332.

Lam, S.Y., Shankar, V., Erramilli. K.M. \& Murthy, B. (2004) Customer Value, Satisfaction, Loyalty, and Switching Costs: An Illustration From a Business-to-Business Service Context, Journal of the Academy of Marketiag Science, 32(3): 293-311.

Lee, H., Lee, Y. \& Yoo, D. (2000) The determinants of perceived service quality and its relationship with satisfaction, Journal of Services Marketing, 14(3): 217-231.

Lonial, S., Menezes, D., Tarim, M., Tatoglu, E. \& Zaim, S. (2010) An evaluation of SERVQUAL and patient loyalty in an emerging country context, Total Quality Management, 21(8): 813-827.

Mandhachitara, R. \& Poolthong, Y. (2011) A model of customer loyalty and corporate social responsibility, Journal of Services Marketing, 25(2): 122-133.

Molina, L.M., Llorens-Montes J. \& RuizMoreno, A. (2007) Relationship between quality management practices and knowledge transfer, Journal of Operations Management, 25: 682-701.

Oliver, R.L. (1980) A Cognitive Model of the Antecedents and Consequences of Satisfaction Decisions, Journal of Marketing Research, 17: 460-469.

Oliver, R.L. (1981) Measurement and Evaluation of Satisfaction Process in Retail Settings, Journal of Retailing, 57(3): 25-48.

Oliver, R.L. (1999) Whence Consumer Loyalty?, Journal of Marketing, 63: 33-44.

Olorunniwo, F., Hsu, M.K. \& Udo, G.J. (2006) Service quality, customer satisfaction, and behavioral intentions in the service factory, Journal of Services Marketing, 20(1): 59-72.

O'Neill, M. (2003) The influence of time on student perceptions of service quality, Journal of Educational Administration, 
41(3): 310-324.

O'Neill, M. \& Palmer, A. (2001) Survey timing and consumer perceptions of service quality: an overview of empirical evidence, Managing Service Quality, 11(3): 182-190.

Parasuraman, A., Zeithaml, V.A. \& Berry, L.L. (1985) A Conceptual Model of Service Quality and Its Implications for Future Research, Journal of Marketing, 49: 41-50.

Parasuraman, A., Zeithaml, V. \& Berry, L. (1988) SERVQUAL: A Multiple-Item Scale for Measuring Consumer Perceptions of Service Quality, Journal of Retailing, 64: 1240.

Parasuraman, A., Zeithaml, V.A. \& Berry, L.L. (1991) Refinement and Reassessment of the SERVQUAL Scale, Journal of Retailing, 67(4): 420-450.

Reichheld, F.F. (1996) Learning from Customer Defections, Harvard Business Review, 74(2): 65-69.

Shankar, V., Smith, A.K., Rangaswamy, A. (2003) Customer Satisfaction and Loyalty in Online and Offiine Environments, International Journal of Research in Marketing, 20(2): 153-175.

Spreng, R.A. \& Mackoy, R.D. (1996) An Empirical Examination of a Model of Perceived Service Quality and Satisfaction, Journal of Retailing, 72(2): 201-214.

Statistical Office of the Republic of Serbia, Available http://webrzs.stat.gov.rs/WebSite/Public/PageView.as px?pKey=127 (accessed 08 September 2011).

Sultan, P. \& Wong, H. (2010) Performance-based service quality model: an empirical study on Japanese universities, Quality Assurance in Education, 18(2): 126143.

Sureshchandar, G.S., Rajendran, C. \& Anantharaman, R.N. (2002) Determinants of customer-perceived service quality: a confirmatory factor analysis approach, Journal of Services Marketing, 16(1): 9-34.
Sursock, A., Smidt, H. (2010) Trends 2010: a decade of change in European Higher Education, European University Association, www.eua.be, (accessed 25 August 2011).

The Service Economy, Organization for Economic Co-operation and Development, 2000; Available at: www.oecd.org, (accessed 04 May 2010).

Tian-Cole, S. \& Crompton, J.L. (2003) A conceptualization of the relationships between service quality and visitor satisfaction, and their links to destination selection, Leisure Studies, 22: 65-80.

Vilares, M.J. \& Coelho, P.S. (2003) The employee-customer satisfaction chain in the ECSI model, European Journal of Marketing, 37(11/12): 1703-1722.

Wiers-Jensen, J., Tensaker, B. \& Grogaard, J.B. (2002) Student Satisfaction: towards an empirical deconstruction of the concept, Quality in Higher Education, 8(2): 183-195.

Zeithaml, V.A., Berry, L.L. \& Parasuraman, A. (1996) The Behavioral Consequences of Service Quality, Journal of Marketing, 60: 3146.

Živković, D., Živković, Ž., Manasijević, D. \& Kostadinović, M. (2010) Investigation of the knowledge combination interrelations between SMEs and consumer/supplier network, Serbian Journal of Management, 5(2): 261-269. 